doi: 10.1054/ bjoc.2000.1312, available online at http://www.idealibrary.com on IDE

\title{
Reproductive factors are crucial in the aetiology of breast cancer - a reply
}

Sir,

The letter by Professor Khuder raises several points of potential importance. Our statistical analysis correlating Mus species and human breast cancer (HBC) incidence is described as simplistic, ignoring social, cultural and demographic variables. Thus, it may suffer from ecological bias, due to the effect of hormonal promoters on the development of HBC. The greatest influence would likely be associated with fecundity, which is best reflected in the world statistics on 'total fertility rate' (TFR) (US Bureau of the Census, Report WP/98, World Population Profile (1998) US Government Printing Office: Washington DC, 1999).

TFR was evaluated as a potential confounder of the association of $M$. domesticus geography with human breast cancer incidence. For our sample of 39 countries (less two regions, Hawaii and 'circumpolar Inuit' for want of data), we analysed the reported 1990 (or 1998, where lacking) TFR for correlation with the world age-standardized incidence rate (WASIR) for female breast cancer (as in Stewart et al, 2000). The expected negative correlation of WASIR with TFR $[R=-0.327, P=0.048]$ was found. However, across Europe there was no difference in TFR between lands of $M$. domesticus and lands of other mice (mean TFR $1.656 \pm$ SD 0.368 , vs $1.657 \pm 0.346, P=0.993)$.

Internationally, excluding Europe, there was a higher reported TFR in M. domesticus lands (TFR $2.875 \pm 0.822$ vs $2.371 \pm 0.971$, $P=0.244)$. Overall, the crude difference in mean WASIR due to M. domesticus lands is +15.6 , accounting for $38.3 \%$ of the observed variation in this sample. The TFR-adjusted difference in mean WASIR is +17.4 , accounting for $48.4 \%$ of variation, both highly statistically significant $(P<0.001)$. Thus, in addressing Professor Khuder's concern about reproductive factors by adjusting for TFR, the association of WASIR with lands of $M$. domesticus was strengthened.

The report by McCredie et al (1999) on the incidence of HBC in Maori and non Maori women emphasizes that all parameters suggesting a lower incidence of HBC were seen in Maori women in a highly significant fashion, lower educational level, lower socio-economic status, lower age at first full term pregnancy, high parity and longer duration of breast-feeding. Despite this, the incidence of HBC in Maori women before the age of 54 is twice that of non-Maori women in New Zealand. Could this reflect a greater exposure of the Maori to Mus domesticus which occurs in both urban areas and native forests in New Zealand (King, 1982)?

In the paper by Chie et al (1995), no data on the incidence of $\mathrm{HBC}$ in white women is given in the text. White women form a minuscule proportion of the female population of Taiwan. The use of oral contraceptives in Asian women migrating to the USA, adjusted for age, ethnicity, study area, years since migration, family history of HBC and age at first full-term birth was not associated with increased risk of breast cancer (Ursin et al, 1999). The low incidence of HBC in Spanish women and Hispanic women living in the US is a fact. Genetic susceptibility to MMTV was not addressed in our paper, although it has been well studied in mice (Ross et al 1997; Golovkina, 2000).

In summary, adjustment of our analysis for a possible ecologic bias related to fecundity and hormonal influence on breast cancer increases the statistical significance of our reported association. We agree with Professor Khuder that one should seek a correlation in breast-cancer risk with more direct measures of contact and potential exposures to mice, such as local mouse population levels, or occupational exposures such as in farming (Khuder et al, 1998), or in laboratory work with experimental handling of mice (Dion et al, 1986). Some areas of the world do have wide fluctuations in M. domesticus population levels due to epizootic diseases, or climatic variations. One must keep in mind that the MMTV is the proposed cause, and that $M$. domesticus would be a surrogate of MMTV exposure. The actual risk will depend on the likely modes of MMTV transmission, exposure, and the burden of infectious MMTV in the resident mouse population.

THM Stewart, CA Donnelly, RD Sage, DW Cameron, AFR Stewart

\section{REFERENCES}

Chie WC, Chen CF, Chen CJ, Chang CL, Liaw YP and Lin RS (1995) Geographic variation of breast cancer in Taiwan: international and migrant comparison. Anticancer Res 15: 2745-2749

Golovkina TV (2000) A novel mechanism of resistance to mouse mammary tumor virus infection. $J$ Virol 74: 2752-2759

Dion AS, Girardi AJ, Williams CC and Pomenti AA (1986) Serologic responses to murine mammary tumor virus (MuMTV) in MuMTV-exposed laboratory personnel. J Natl Cancer Inst 76: 611-619

Khuder SA, Schaub EA and Keller-Byrne JE (1998) Meta-analyses of nonHodgkin's lymphoma and farming. Scand J Work Environ Health 24: 255-261

King CM (1982) Age structure and reproduction in feral New Zealand populations of the house mouse (Mus musculus), in relation to seedfall of southern beech. New Zealand J Zool 9*: 467-480

McCredie M Paul C, Skegg DC and Williams S (1999) Breast cancer in Maori and non-Maori women. Int J Epidemiol 28: 189-195

Ross SR, Dzuris JL, Golovkina TV, Clemmons WC and van den Hoogen B (1997). Mouse mammary tumor virus (MMTV), a retrovirus that exploits the immune system. Genetics of susceptibility to MMTV infection. Medicina (B Aires) 57: $34-42$

Stewart TH, Sage RD, Stewart AF and Cameron DW (2000) Breast cancer incidence highest in the range of one species of house mouse, Mus domesticus. Br J Cancer 82: 446-451

Ursin G Wu AH, Hoover RN, West DW, Nomura AM, Kolonel LN, Pike MC and Ziegler RG (1999) Breast cancer and oral contraceptive use in Asian-American women. Am J Epidemiol 150: 561-567 